\title{
Peptide Growth Factor Phytosulfokine-a Stimulates Cell Divisions and Enhances Regeneration from B. oleracea var. capitata L. Protoplast Culture
}

\author{
Agnieszka Kiełkowska $^{1}$ (D) Adela Adamus ${ }^{1}$
}

Received: 21 June 2018 / Accepted: 12 November 2018 / Published online: 28 December 2018

(c) The Author(s) 2018

\begin{abstract}
Protoplasts of six cabbage accessions were isolated from leaf mesophyll and cultured in the presence of $0.01,0.1$ and $1.0 \mu \mathrm{M}$ phytosulfokine- $\alpha$ (PSK- $\alpha$ ) and in a PSK-free control medium. PSK- $\alpha$ was applied for 10 days and later, protoplast-derived cells were cultured in the PSK-free medium. Supplementation of the culture medium with PSK- $\alpha$ showed a dose-dependent effect on the mitotic activity of cultured cells. On the 15th day of culture, the highest mitotic activity of protoplast-derived cells was observed in cultures treated with $0.1 \mu \mathrm{M}$ of PSK- $\alpha$, and ranged from 14 to $60 \%$ dependent on the accession. The number of multi-cell structures was also higher (90-93\%) on this medium compared to the control (77-80\%). Analysis of cellulose regeneration in cultured protoplasts after Calcofluor White staining showed that this process was not synchronous, but depended instead on the presence of PSK- $\alpha$ in the culture medium, and was more pronounced in the low-responding accession. Sustained cell divisions led to formation of microcallus colonies, subjected to regeneration on solid media. Supplementation of the regeneration media with $0.1 \mu \mathrm{M}$ of PSK significantly increased shoot regeneration compared to the control media. Moreover, enhanced regeneration was observed from calluses developed from cells treated with PSK- $\alpha$ at the early stages of development and later transferred for regeneration onto the media supplemented with $0.1 \mu \mathrm{M}$ of this peptide.
\end{abstract}

Keywords Alginate $\cdot$ Calcofluor $\cdot$ Leaf protoplasts $\cdot$ Mitosis $\cdot$ PSK- $\alpha \cdot$ Shoot regeneration

\section{Introduction}

Peptide growth factors (peptide signalling molecules) are proteins of a multifunctional nature, exerting diverse biological effects through interactions with cellular receptors that function as ligand activated intracellular enzymes (Sporn and Roberts 1991). The enzymatic pathways that are initiated by the binding of a growth factor to its receptor lead to long-term changes in gene expression and protein biosynthesis that alter cell phenotype, having profound effects on the growth and development of a whole organism (Lindsey et al. 2002). In animals, many peptide growth factors have been identified and characterized, and beside their importance in different areas of biology, they also have

Agnieszka Kiełkowska

a.kielkowska@urk.edu.pl

1 Unit of Genetics Plant Breeding and Seed Science, Faculty of Biotechnology and Horticulture, Institute of Plant Biology and Biotechnology, University of Agriculture in Krakow, Al. 29-Listopada 54, 31-425 Krakow, Poland therapeutic uses. Peptide signal molecules play a significant role in regulating somatic growth, modulating intermediary metabolism, exerting proliferative effects on cells, influencing tissue maturation, playing a role in the repair of soft and hard tissues, immunosupression, and the enhancement of immune cell function and treatment of some proliferative diseases, including cancer (Rotwein 1997). For many years, the signalling molecules were considered to be specific to animal systems; however, steroids (brassinosteroids), sterols, nitric oxide, lipid derivatives (jasmonate, isoprenoid lipids) and salicylates have been recognized as signal molecules in plants (Reymond and Farmer 1998; Jang et al. 2000; Bishop and Yakota 2001; Arasimowicz and Floryszak-Wieczorek 2007). Further studies have allowed the discovery of peptides having signalling roles in intracellular communication and development in plants (Lindsey et al. 2002). To this group belong the systemins and systemin-like peptides (first discovered), identified as a component of the systemic wound response in the Solanace family (Pearce et al. 1991; Constabel et al. 1998); CLAVATA3 peptides found in Arabidopsis and involved in shoot apical meristem organization 
(Fletcher et al. 1999); the ENOD40 gene in rice and leguminous species encoding small (10-13 amino acids) peptides involved in root nodulation (van de Sande et al. 1996); S-Locus Cysteine Rich Protein $\left(\mathrm{SCR}, \mathrm{SP}_{11}\right)$ plays a role in self-incompatibility in the Brassiceace family (Vanoosthuyse et al. 2001); and phytosulfokines (PSK), detected in suspension cell cultures of Asparagus officinalis (Matsubayashi and Sagakami 1996), having mitogenic activity.

Phytosulfokines (PSK- $\alpha$ and PSK- $\beta$ ) are small (five and four amino acids, respectively) disulfated peptides. Sulfonylation of the two tyrosyl side chains of a phytosulfokine determines its biological activity (Matsubayashi et al. 1996). PSK- $\beta$ is a product of enzymatic degradation of PSK- $\alpha$ and it has weaker biological activity compared to PSK- $\alpha$ (Matsubayashi et al. 1996). Although PSK was originally detected as a secreted peptide in conditioned medium, results have indicated that its molecules are also produced in intact plants (Yang et al. 1999b). PSK precursor genes are encoded by small gene families present in higher plants and not found in lower plants. In Arabidopsis, five expressed PSK genes have been identified and designated AtPSK1-AtPSK5, and two genes encode the PSK receptors (AtPSKR1, AtPSKR2) (Lorbiecke and Sauter 2002; Stührwohldt et al. 2015). PSK precursor genes display differential expression throughout the plant life cycle and exhibit tissue-type specific expression; for example, AtPSK1 is expressed in roots, AtPSK2 is expressed in the ovule following fertilization, whereas other genes are expressed in the roots and shoots (Kutschmar et al. 2009; Stührwohldt et al. 2011). In planta, PSK promotes cell growth mainly by enhancing cell expansion (Kutschmar et al. 2009), it also contributes to the formation and maintenance of the root apical meristem (Matsuzaki et al. 2010), as well as to pollen tube growth, by redirecting the pollen tube towards an embryo sac (Stührwohldt et al. 2015). PSK also alters plant responses during pathogen infection (Mosher et al. 2013) and maintains the growth of plants exposed to abiotic stress (Yamakawa et al. 1999). In vitro, PSK enhances callus growth in Arabidopsis thaliana (Matsubayashi et al. 2006), adventitious root formation in Cucumis sativus (Yamakawa et al. 1998) and adventitious bud formation in Anthirrhnum majus (Yang et al. 1999a). It also enhances somatic embryogenesis in Daucus carota (Hanai et al. 2000), Cryptomeria japonica (Igasaki et al. 2003), and Larix leptolepis (Umehara et al. 2005a), microspore embryogenesis in Triticale and Triticum aestivum (Asif et al. 2014), and cell proliferation in A. officinalis (Matsubayashi and Sagakami 1996), Oryza sativa (Matsubayashi et al. 1997), Beta vulgaris (Grzebelus et al. 2012) and Daucus spp. (Maćkowska et al. 2014). Most recent findings showed that PSK enhanced the regeneration competence in some recalcitrant legumes (Ochatt et al. 2018).

Protocols for isolating and culturing protoplasts are published for a range of plants, but this has only resulted in obtaining valuable somatic hybrids in a small group of plants, including rice, potato, tobacco, citrus and rapeseed (Waara and Glimelius 1995; Davey et al. 2005; Grosser and Gmitter 2005). The main problem with using protoplast cultures in breeding programs lies in the lack of efficient protoplast-to-plant regeneration systems for many important crop species (Grosser and Gmitter 2005; Lakshmanan et al. 2013). Brassica oleracea is a plant species that includes many common foods such as cabbage, broccoli, kale, kohlrabi, and cauliflower. The extensive screening of protoplast culture in B. oleracea showed that the effect of genotype overrides the wide use of protoplast techniques in the breeding and biotechnology of this species (Jourdan et al. 1990; Kik and Zaal 1993; Zhao et al. 1995; Kiełkowska and Adamus 2012, 2014); therefore, improvements in the methodology aiming to increase the mitotic activity of cultured protoplasts and plant regeneration are needed.

Our preliminary results showed that PSK added to the culture medium stimulated protoplast proliferation especially in low-responding cabbage genotypes (Kiełkowska and Adamus 2017). This study aims to evaluate the effects of broader spectra of PSK- $\alpha$ concentration in the culture medium on cabbage protoplasts, as well as its effect on cell wall regeneration. The effect of direct supplementation of a solid medium with PSK- $\alpha$ on the regeneration process was also examined.

\section{Materials and Methods}

\section{Plant Material}

Seeds of B. oleracea var. capitata f. alba cv's Kamienna Głowa (PlantiCo, PL), Sława z Gołębiewa (PlantiCo, PL), Oregon 123 (Warwick Genetic Resources Unit, GB), and three breeding lines: LM, LM98 and LM153 (KHiNO Polan, PL), were used. Seeds were surface sterilized in $70 \%$ $(v / v)$ ethanol for $2 \mathrm{~min}, 10 \%(w / v)$ chloramine $\mathrm{T}$ (Biochemie Poland, PL) for $20 \mathrm{~min}$, and washed three times with sterile distilled water for 5 min each and air dried. Seeds were placed in sterile $500 \mathrm{ml}$ culture boxes (Pakler Lerka, PL) containing $80 \mathrm{ml}$ of MS (Murashige and Skoog 1962) medium supplemented with $20 \mathrm{~g} \mathrm{l}^{-1}$ sucrose and $0.28 \%(\mathrm{w} / \mathrm{v})$ Gelrite (Sigma-Aldrich) and kept at $26 \pm 2{ }^{\circ} \mathrm{C}$ with a $16-\mathrm{h}$ photoperiod with a light intensity of $55 \mu \mathrm{mol} \mathrm{m}{ }^{-2} \mathrm{~s}^{-1}$.

\section{Protoplast Isolation and Culture}

Protoplasts were isolated from leaves of 4-week-old in vitro grown plants (Fig. 1a). Leaves were cut into fine pieces and subjected to plasmolysis in $0.5 \mathrm{M}$ mannitol, $\mathrm{pH}$ 5.8 for $1 \mathrm{~h}$ at $25^{\circ} \mathrm{C}$ in the dark. After removal of the plasmolysis solution, the tissue was treated with an enzyme 

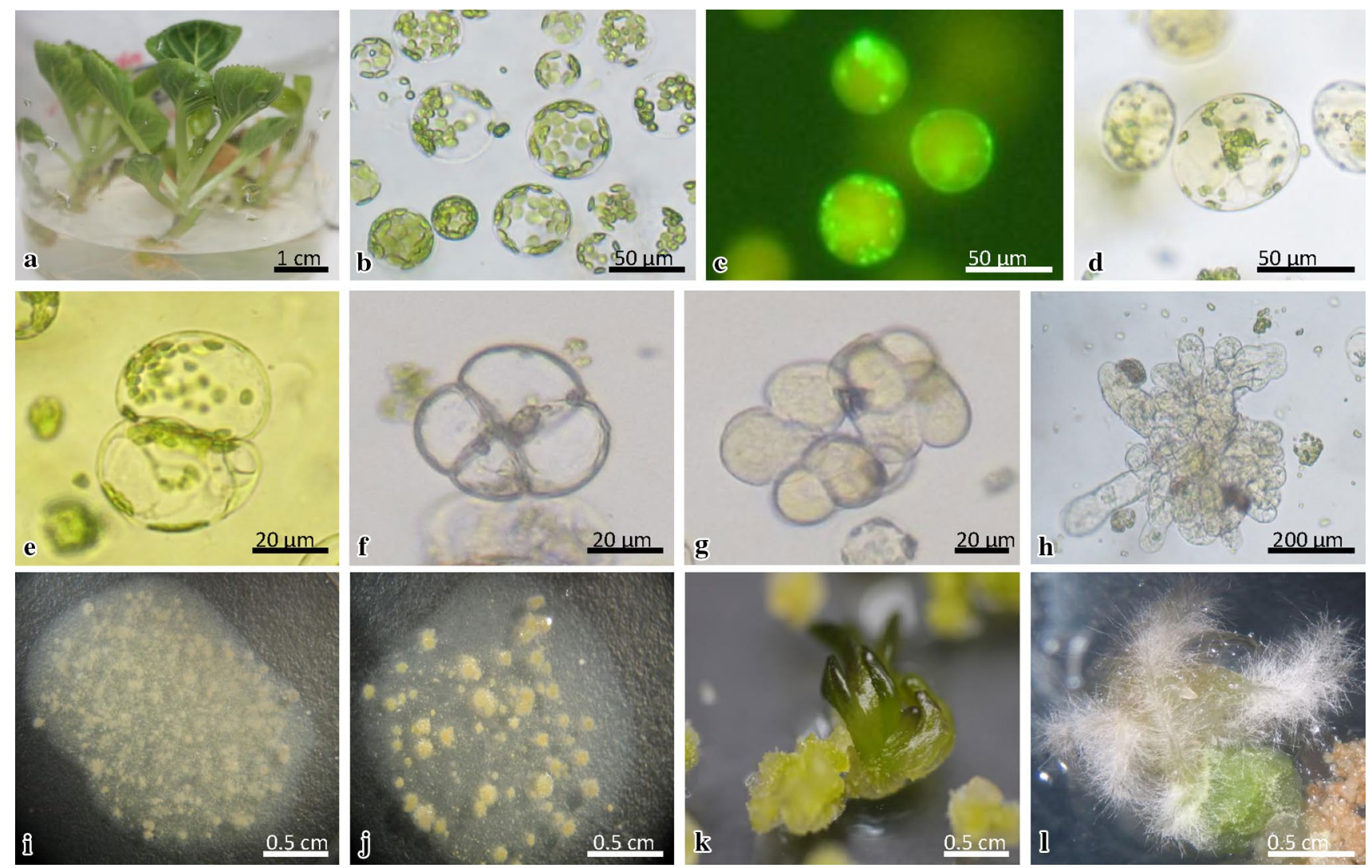

Fig. 1 Development of leaf protoplast cultures of Brassica oleracea. a donor material, $\mathbf{b}$ freshly isolated leaf protoplasts, $\mathbf{c}$ fluorescence of viable protoplasts stained with FDA, $\mathbf{d}$ enlarged protoplast before first division, e first cell division, $\mathbf{f}$ second cell division (four cell struc-

ture); cell colony formation: $\mathbf{g}$ eight-cell structure, $\mathbf{h}$ multi-cell aggregate, $\mathbf{i}, \mathbf{j}$ alginate layer overgrown with callus colonies differing in size; organogenesis from protoplast-derived cells: shoot (k) and root (l) formation

solution consisting of $0.5 \%(w / v)$ cellulase Onozuka R-10 (Duchefa Biochemie, NL), 0.1\% (w/v) pectolyase Y-23 (Duchefa), $3 \mathrm{mM} \mathrm{CaCl}, 2 \mathrm{mM}$ of 2-(N-morpholino) ethanesulfonic acid (MES) (Sigma-Aldrich), and $0.4 \mathrm{M}$ mannitol, pH 5.8, filter sterilized (0.22 $\mu \mathrm{m}$; Millipore, GB). The dishes with tissues were placed on a gyratory shaker $(20 \mathrm{rpm})$ and incubated in an enzyme solution for approximately $18 \mathrm{~h}$ at $25^{\circ} \mathrm{C}$ and in the dark. Then, the solution was filtered through a nylon sieve $(100 \mu \mathrm{m}$, Millipore) and centrifuged at $101 \times \mathrm{g}$ for $5 \mathrm{~min}$. Pellets were re-suspended in $0.5 \mathrm{M}$ sucrose with $1 \mathrm{mM}$ MES, overlaid with $2 \mathrm{ml}$ of W5 salt solution consisting of $154 \mathrm{mM}$ $\mathrm{NaCl}, 125 \mathrm{mM} \mathrm{CaCl} 2 \cdot 2 \mathrm{H}_{2} \mathrm{O}, 5 \mathrm{mM} \mathrm{KCl}, 5 \mathrm{mM}$ glucose, pH 5.8 (Menczel et al. 1981), and centrifuged $(145 \times \mathrm{g}$, $10 \mathrm{~min}$ ). Protoplasts, localized in the interphase between sucrose/MES and the W5 solution were gently collected into a new tube, suspended in W5 solution and centrifuged $(101 \times \mathrm{g}, 5 \mathrm{~min})$. The pellet was diluted in culture medium consisting of macro-, micro-elements and organic acids according to Kao and Michayluk (1975), vitamins according to B5 medium (Gamborg et al. 1968), $250 \mathrm{mg} \mathrm{l}^{-1}$ casein hydrolysate, $74 \mathrm{~g} \mathrm{l}^{-1}$ glucose, $0.1 \mathrm{mg}$

$1^{-1}$ 2,4-dichlorophenoxyacetic acid (2,4-D) and $0.2 \mathrm{mg}$ $1^{-1}$ zeatin, $\mathrm{pH} 5.6$, filter sterilized $(0.22 \mu \mathrm{m}$; Millipore). Protoplast yield was counted using a haemocytometer and the density of cultured protoplasts was adjusted to $8 \times 10^{5}$ per millilitre of culture medium. Then protoplasts were immobilized in calcium alginate layers according to Kiełkowska and Adamus (2012, 2014). Briefly, equal volumes of protoplast suspension and alginate solution $(2.8 \%$ $(w / v)$ alginic acid sodium salt (Sigma-Aldrich), $0.4 \mathrm{M}$ mannitol, pH 5.8, filter sterilized) were mixed to obtain final culture density of $4 \times 10^{5}$ per ml. Alginate layers were obtained by spreading $400 \mu$ l protoplast-alginate mixture onto $60 \mathrm{~mm}$ Petri dishes containing calcium-agar media (40 $\mathrm{mM} \mathrm{CaCl}_{2}, 0.4 \mathrm{M}$ mannitol, 1\% (w/v) agar (Biocorp, PL), pH 5.8, autoclaved (20 min, $\left.121^{\circ} \mathrm{C}, 0.1 \mathrm{MPa}\right)$. After $1 \mathrm{~h}$ incubation at room temperature, the alginate polymerized forming solid layers with embedded protoplasts. Alginate layers were transferred to $60 \mathrm{~mm}$ Petri dishes containing $4 \mathrm{ml}$ of culture medium. The culture medium was supplemented with either $0.01,0.1$ or $1.0 \mu \mathrm{M}$ of PSK- $\alpha$ (PeptaNova GmbH, DE). Immobilized protoplasts cultured in the medium without PSK- $\alpha$ were used as a 
control. Cultures were incubated in the dark at $26 \pm 2{ }^{\circ} \mathrm{C}$. The culture medium was renewed once after 10 days. Fresh medium did not contain PSK- $\alpha$.

\section{Microscopic Observations}

Protoplast viability was estimated on the first and fifth days of culture by staining with fluorescein diacetate (FDA). The FDA working solution consisted of $60 \mu \mathrm{l}$ of $0.3 \%$ FDAacetone stock solution (filter-sterilized) and $4 \mathrm{ml}$ of culture medium. Then, $100 \mu$ l of working solution was added to the Petri dishes with immobilized protoplasts. Observations of yellow-green fluorescence of viable cells were performed using an Axiovert S100 (Carl Zeiss, Göttingen, $\mathrm{DE})$ inverted microscope equipped with the necessary filters $\left(\lambda_{\mathrm{Ex}}=485 \mathrm{~nm}, \lambda_{\mathrm{Em}}=515 \mathrm{~nm}\right)$.

Cell divisions were counted on the fifth and fifteenth days of culture with the use of an Axiovert S100 microscope under white light. Prior to tracking the developmental stage of the cultured cells in dependency on the presence of PSK in the medium, we ran an experiment choosing the highest (LM153) and lowest responding (Oregon 123) accessions in media supplemented with $0.1 \mu \mathrm{M}$ of PSK- $\alpha$. PSK-free medium was used as the control. The data were collected with respect to the presence of 2-cell, 4-8-cell and multi-cell structures (Fig. 1f-h) at days 5 and 15 during the culture.

Fluorescent Brightener 28 (Calcofluor White M2R, Sigma-Aldrich) was used for cellulose staining; a $0.01 \%$ water solution of Calcofluor was added to the culture dish with protoplasts and left for $10 \mathrm{~min}$ in dark. Bright blue fluorescence of cellulose was observed under UV light in Axiovert S100 microscope with proper filters $\left(\lambda_{\mathrm{Ex}}=365 \mathrm{~nm}\right.$, $\lambda_{\mathrm{Em}}=420 \mathrm{~nm}$ ). Observations were made for two accessions, Oregon 123 and LM153, after 24, 48 and $72 \mathrm{~h}$ of culture.

Callus colonies were counted in the fourth week of culture. Each Petri dish containing an alginate layer covered by developing callus colonies was observed under a stereomicroscope Leica S6D (Leica Microsystems). Callus clumps at least $0.5 \mathrm{~mm}$ in size were counted. After counting, callus colonies were transferred for regeneration.

\section{Shoot Regeneration}

Protoplast-derived callus colonies were freed from alginate layers by depolymerization. The layers were incubated for $1 \mathrm{~h}$ at room temperature in a solution consisting of $20 \mathrm{mM}$ sodium citrate and $0.2 \mathrm{M}$ mannitol, $\mathrm{pH}=5.8$, autoclaved (20 min, $121{ }^{\circ} \mathrm{C}, 0.1 \mathrm{MPa}$ ). The suspension was then centrifuged at $64 \times \mathrm{g}$ for $5 \mathrm{~min}$. The pellet was resuspended in culture medium containing $0.1 \mathrm{mg}^{-1}$ a-naphthaleneacetic acid (NAA), $0.2 \mathrm{mg} \mathrm{l}^{-1}$ zeatin, $\mathrm{pH}=5.6$ (Dirks et al. 1996) and centrifuged $(64 \times \mathrm{g}, 5 \mathrm{~min})$. The released callus colonies were transferred to a filter paper placed onto solid regeneration medium. The filter paper was removed after 2 weeks. Two types of regeneration media were used fullstrength MS (Murashige and Skoog 1962) without growth regulators and B5B medium consisting of B5 (Gamborg et al. 1968) micro-, macro-elements and vitamins with $750 \mathrm{mg} \mathrm{l}^{-1} \mathrm{CaCl}_{2} 2 \mathrm{H}_{2} \mathrm{O}, 1.0 \mathrm{mg} \mathrm{l}^{-1}$ 6-benzyladenine (BA). Both media were supplemented with $20 \mathrm{~g} \mathrm{l}^{-1}$ sucrose and $0.25 \%(w / v)$ Gelrite (Sigma-Aldrich), pH 5.7-5.8, autoclaved ( $20 \mathrm{~min}, 121^{\circ} \mathrm{C} ; 0.1 \mathrm{MPa}$ ). MS and B5B media were supplemented with $0.1 \mu \mathrm{M}$ of PSK- $\alpha$. Both regeneration media without PSK- $\alpha$ were used as control media. Cultures were kept in dimmed light for 2 weeks and later maintained at $26 \pm 2{ }^{\circ} \mathrm{C}$ with a $16 \mathrm{~h}$ photoperiod at a light intensity of $55 \mu \mathrm{mol} \mathrm{m}{ }^{-2} \mathrm{~s}^{-1}$. Cultures were transferred to fresh medium every 4 weeks. The frequency of shoot regeneration from a callus was evaluated after 12 weeks of culture.

\section{Statistical Analysis}

A single experiment consisted of four independent protoplast isolations with a single treatment represented by four Petri dishes. Microscopic observations were performed in five random microscopic fields on approximately 200 cells per Petri dish. The experiment was repeated three times. The viability of protoplasts was calculated as the number of protoplasts with yellow-green fluorescence (Fig. 1c) divided by the total number of observed cells $(\times 100)$. Cellulose regeneration was calculated as the percentage of cells with bright-blue fluorescence covering the whole cell surface, part of the cell surface and cells without fluorescence. Division frequency was expressed as the number of dividing protoplast-derived cells per total number of observed cells $(\times 100)$. The number of cells in a particular developmental stage (2-cell, 4-8 cell and multi-cell) were also collected and expressed in percentages. Callus production was expressed as the mean number of callus clumps at least $0.5 \mathrm{~mm}$ in size, developed on a single Petri dish. Regeneration frequency was calculated as the number of regenerated shoots per total number of calli cultured on the regeneration medium $(\times 100)$. Analyses were performed using Statistica ver. 12.0 (Statsoft Poland Inc., PL) with the ANOVA module. Mean separation was performed with Tukey's honest significant difference (HSD) test.

\section{Results}

\section{Viability and Mitotic Activity of Protoplast-Derived Cells}

Protoplasts were isolated from mesophyll tissue of all tested accessions with a yield allowing for successful culture establishment. Protoplasts after isolation were spherical with 
Table 1 Effect of accession and phytosulfokine- $\alpha$ (PSK- $\alpha$ ) on the viability of B. oleracea protoplast-derived cells

\begin{tabular}{lllll}
\hline Factor & \multicolumn{3}{l}{ Viability $(\% \pm \mathrm{SE})$ in } \\
\cline { 2 - 5 } & 1st day & & 5th day & \\
\hline Accession & & & & \\
Kamienna Głowa & $83.1 \pm 0.7$ & $\mathrm{c}$ & $54.2 \pm 1.1$ & $\mathrm{~d}$ \\
Sława z Gołębiewa & $79.2 \pm 0.8$ & $\mathrm{~d}$ & $61.3 \pm 1.1$ & $\mathrm{c}$ \\
Oregon 123 & $86.1 \pm 0.7$ & $\mathrm{~b}$ & $57.0 \pm 1.0$ & $\mathrm{~d}$ \\
LM & $84.2 \pm 0.7$ & $\mathrm{c}$ & $70.2 \pm 0.8$ & $\mathrm{~b}$ \\
LM98 & $78.6 \pm 0.9$ & $\mathrm{~d}$ & $64.5 \pm 1.2$ & $\mathrm{c}$ \\
LM153 & $88.3 \pm 0.7$ & $\mathrm{a}$ & $74.9 \pm 1.1$ & $\mathrm{a}$ \\
PSK- $\alpha$ concentration $(\mu \mathrm{M})$ in liquid culture media & & \\
0 & $80.4 \pm 0.6$ & $\mathrm{~b}$ & $60.1 \pm 0.8$ & $\mathrm{~b}$ \\
0.01 & $84.0 \pm 0.7$ & $\mathrm{a}$ & $66.5 \pm 0.9$ & $\mathrm{a}$ \\
0.1 & $86.4 \pm 0.5$ & $\mathrm{a}$ & $67.1 \pm 1.0$ & $\mathrm{a}$ \\
1.0 & $82.2 \pm 0.7$ & $\mathrm{~b}$ & $61.0 \pm 0.9$ & $\mathrm{~b}$ \\
\hline
\end{tabular}

Means for each factor denoted with the same letter are not significantly different ( $p \leq 0.05$, HSD). Values for the factor 'PSK- $\alpha$ concentration $(\mu \mathrm{M})$ in liquid culture media' are means from all tested accessions jointly

randomly distributed chloroplasts (Fig. 1b). Protoplast viability recorded on the first day of culture was relatively high and varied from 78 to $79 \%$ for Sława z Gołębiewa and LM98 up to $88 \%$ in the breeding line LM153 (Table 1). On the fifth day of culture, viability decreased in all tested accessions. Viability above $70 \%$ was observed in breeding lines LM153 and LM. The lowest viability (54-57\%) was observed in cultivars Kamienna Głowa and Oregon 123. There was no difference in the viability of protoplasts cultured in the presence of 0.01 and $0.1 \mu \mathrm{M}$ PSK- $\alpha$ independently from the culture duration; however, it was higher than in control cultures. Viability of protoplasts cultured in the presence of the highest concentration of PSK- $\alpha(1.0 \mu \mathrm{M})$ was similar to control.

Three to four days after isolation, protoplasts changed their shape and enlarged, chloroplasts present in abundance after isolation, now started to disappear. Inside the cells, clear cytoplasmic strands were visible (Fig. 1d) and the first mitotic divisions occurred (Fig. 1e). In 5-day-old cultures, 6-24\% of observed protoplast-derived cells underwent divisions (Table 2). Ten days later, the frequency of cell division increased considerably. The highest (54\%) mitotic activity was observed in cultures of the breeding line LM153, and this was nearly $10 \%$ lower in line LM. The lowest (14\%) frequency of cell divisions was observed in Oregon 123.

In 5-day-old cultures, the division frequency of protoplast-derived cells cultured in the control medium was lower (8\%) compared to those cultured in the presence of PSK- $\alpha$ (Table 2). On the 15th day of culture, this tendency was also observed, but the highest percentage (38\%) of mitotic divisions was scored among protoplast-derived cells cultured in the presence of $0.1 \mu \mathrm{M}$ of PSK- $\alpha$ for 10 days.
Table 2 Effect of accession and phytosulfokine- $\alpha$ (PSK- $\alpha$ ) on division frequency of $B$. oleracea protoplast-derived cells

\begin{tabular}{lllll}
\hline Factor & \multicolumn{3}{l}{ Division frequency $(\% \pm$ SE) in } \\
\cline { 2 - 5 } & 5th day & & 15th day & \\
\hline Accession & & & \\
Kamienna Głowa & $12.1 \pm 0.9$ & $\mathrm{c}$ & $29.0 \pm 1.1$ & $\mathrm{c}$ \\
Sława z Gołębiewa & $7.4 \pm 0.5$ & $\mathrm{~d}$ & $21.4 \pm 0.9$ & $\mathrm{~d}$ \\
Oregon 123 & $5.7 \pm 0.6$ & $\mathrm{e}$ & $13.8 \pm 0.7$ & $\mathrm{e}$ \\
LM & $20.2 \pm 0.8$ & $\mathrm{~b}$ & $43.5 \pm 0.9$ & $\mathrm{~b}$ \\
LM98 & $6.0 \pm 0.3$ & de & $21.0 \pm 1.0$ & $\mathrm{~d}$ \\
LM153 & $24.3 \pm 0.9$ & $\mathrm{a}$ & $54.4 \pm 1.3$ & $\mathrm{a}$ \\
PSK- $\alpha$ concentration $(\mu \mathrm{M})$ in liquid culture media & & \\
0 & $7.7 \pm 0.4$ & $\mathrm{c}$ & $21.7 \pm 0.7$ & $\mathrm{c}$ \\
0.01 & $15.3 \pm 0.8$ & $\mathrm{a}$ & $31.9 \pm 1.1$ & $\mathrm{~b}$ \\
0.1 & $14.6 \pm 0.8$ & $\mathrm{a}$ & $37.7 \pm 1.0$ & $\mathrm{a}$ \\
1.0 & $12.7 \pm 0.6$ & $\mathrm{~b}$ & $30.8 \pm 1.1$ & $\mathrm{~b}$ \\
\hline
\end{tabular}

Means for each factor denoted with the same letter are not significantly different ( $p \leq 0.05$, HSD). Values for the factor 'PSK- $\alpha$ concentration $(\mu \mathrm{M})$ in liquid culture media' are means from all tested accessions jointly

Detailed analysis of mitotic activity of protoplast-derived cells of the tested accessions on PSK- $\alpha$ containing media showed that in the best responding accession (breeding line LM153), the division frequency was similar independently of PSK concentration (Fig. 2). For the remaining five accessions, the supplementation of the culture medium with PSK- $\alpha$ showed a beneficial but dose-dependent effect. For three accessions (Kamienna Głowa, Sława z Gołębiewa and LM98), PSK- $\alpha$ applied at all tested concentrations stimulated cell divisions above the control; however, the highest division frequency (30-44\%) was observed in cultures supplemented with $0.1 \mu \mathrm{M}$ of PSK- $\alpha$. For breeding line LM, there was no difference in mitotic activity of protoplastderived cells cultured on the medium with $0.01 \mu \mathrm{M}(49 \%)$ and $0.1 \mu \mathrm{M}(51 \%)$ of PSK- $\alpha$. In cultivar Oregon 123, the highest (21\%) mitotic activity of cultured protoplast-derived cells was observed in cultures supplemented with the highest $(1.0 \mu \mathrm{M})$ concentration of PSK- $\alpha$.

The analysis of the developmental stage of protoplastderived cells (Fig. 3) showed that on the fifth day of culture in the low responding cultivar Oregon 123, 2-cell (Fig. 1e) and 4-8 cell (Fig. 1f, g) colonies were prevalent (83-84\%), irrespective of the presence of PSK- $\alpha$ in the medium. Differences were observed in 15-day-old cultures, where in the control medium, approximately $80 \%$ of observed cells were multi-cell colonies (Fig. 1h), 19\% were 4-8 cell, and $4 \%$ were 2-cell structures. In cultures supplemented with $0.1 \mu \mathrm{M}$ PSK- $\alpha$, nearly $90 \%$ of observed developments were multi-cell colonies, and no 2-cell structures were observed. In 5-day-old cultures of LM153, the percentage of 2-cell structures was lower (24\%) compared to Oregon 123 (37\%), 
Fig. 2 Division frequency of protoplast-derived B. oleracea cells cultured in media supplemented with different concentrations of phytosulfokine- $\alpha$ (PSK- $\alpha)$. Observations were made on the 15th day of culture. Bars represent means \pm SE. Means denoted with the same letter are not significantly different $(p \leq 0.05$, HSD $)$

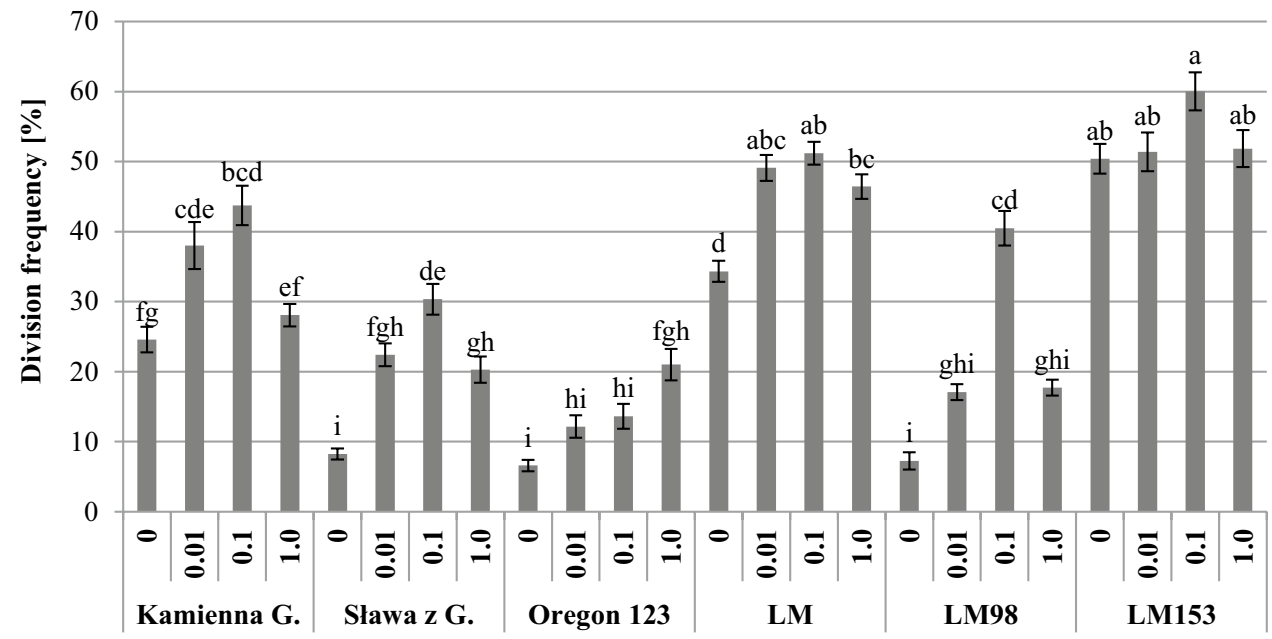

PSK- $\alpha$ concentration $[\mu \mathrm{M}]$ in liquid culture media and accession

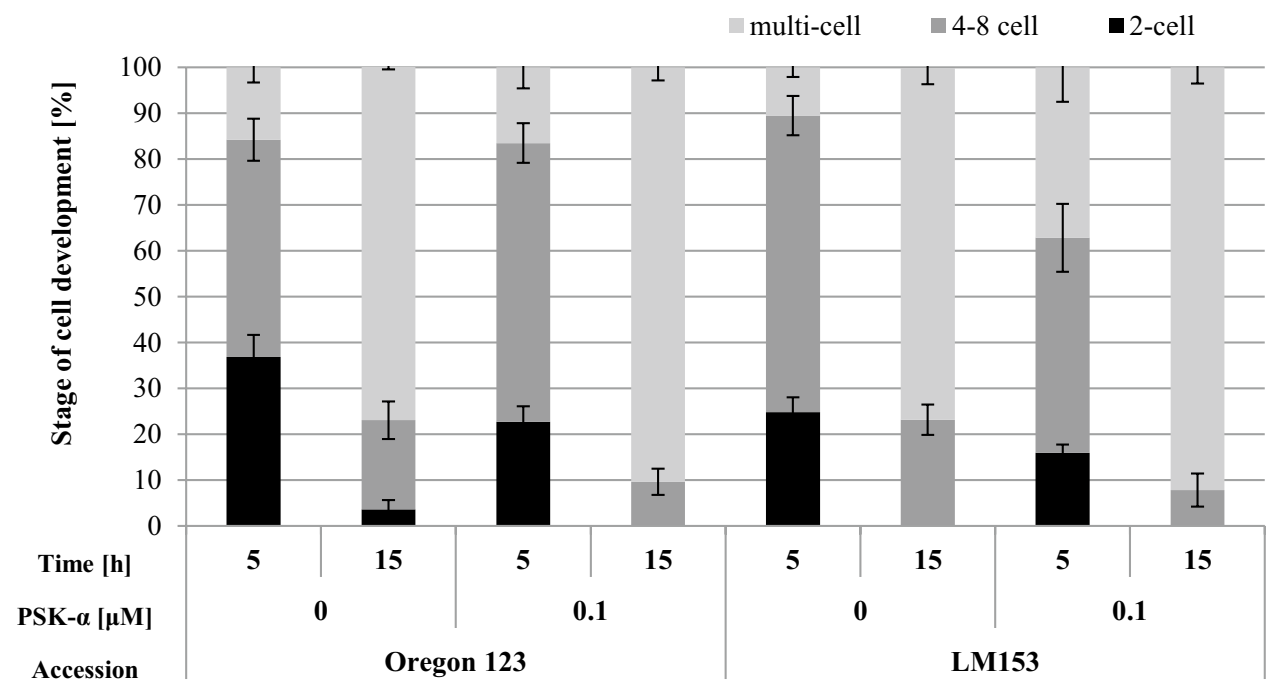

Oregon 123
LM153
Fig. 3 Developmental stage of protoplast-derived B. oleracea cells in dependency on culture duration and supplementation of phytosulfokine- $\alpha$ (PSK- $\alpha$ ) into the culture medium. Bars represent means $\pm \mathrm{SE}$ but 4-8-cell structures were prevalent. After 15 days of culture in the control medium, the majority (77\%) of cells were multi-cell structures, but in cultures grown with $0.1 \mu \mathrm{M}$ PSK- $\alpha$, the percentage of such structures was considerably higher $(92 \%)$.

\section{Cellulose Regeneration}

The process of cellulose resynthesis in cultured protoplasts was not synchronous; however, distinct stages could be identified. Figure 4 shows representative microscopic images of protoplasts at 24-72 h of culture. Some protoplasts showed no staining with Calcofluor White (Fig. 4a-d, red arrows), indicating that the cell walls had been completely degraded, and that cellulose was not resynthetized. In the early stages of culture $(24 \mathrm{~h})$, protoplasts with point-aligned distributions of cellulose were observed, indicating start points of cell wall rebuilding (Fig. 4a-d, yellow arrows). At $72 \mathrm{~h}$ of culture, cellulose was evenly distributed over the cell surface and, in some cells, a thick cell plate was visible, indicating cytokinesis during cell division (Fig. 4e, f).

We found clear differences in the dynamics of cellulose regeneration in cabbage protoplasts dependent on the presence of PSK- $\alpha$ in the medium in Oregon 123, whereas in LM153 differences were less obvious (Fig. 5). After 24 h, in Oregon 123, we observed $37 \%$ of protoplast-derived cells with completely regenerated cellulose, $23 \%$ with partial resynthesis, while the remaining (39\%) showed no fluorescence, indicating a lack of cellulose resynthesis. At the same time, approximately $50 \%$ of cells cultured in presence of $0.1 \mu \mathrm{M}$ PSK- $\alpha$ had evenly distributed cellulose on the whole cell surface, and in only about $23 \%$ of cells, we observed incomplete cellulose regeneration. Later in culture such differences were also observed and, after $72 \mathrm{~h}, 82 \%$ of 


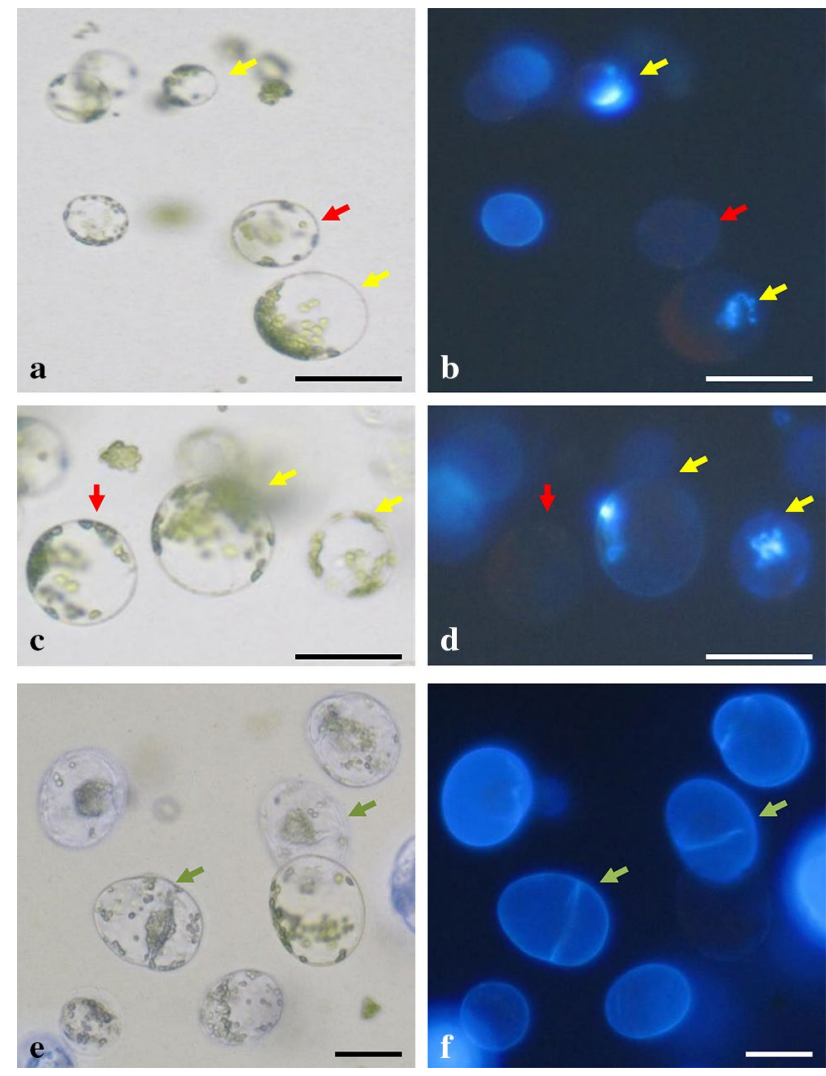

Fig. 4 Regeneration of cellulose in protoplast cultures of Brassica oleracea. Cells of breeding line LM153 stained with Calcofluor White and observed in white (left panel) and UV (right panel) light, respectively: a-d irregular, point-aligned distribution of cellulose on the surface of protoplasts at the 24th h of culture (yellow arrows) and protoplasts lacking cell wall synthesis (red arrows); e, f cells with evenly distributed cellulose at the $72 \mathrm{nd} \mathrm{h}$ of culture, the bright line across the protoplast indicating commencement of cytokinesis (green arrows). Scale bar $50 \mu \mathrm{m}$. (Color figure online) control cells and $90 \%$ of PSK- $\alpha$-treated cells had completely regenerated cell walls. In breeding line LM153 at $24 \mathrm{~h}$ of culture, approximately $57 \%$ of control cells and $63 \%$ of PSK$\alpha$-treated cells had completely resynthesized cellulose on the cell surface. Similarly, after 72 h, $91 \%$ of control cells and $94 \%$ of cells cultured in the medium with $0.1 \mu \mathrm{M}$ of PSK- $\alpha$ had complete cell walls.

\section{Microcallus Production and Shoot Regeneration}

Multi-cell colonies continued to grow and resulted in the formation of microcallus. After approximately 3 weeks of culture, alginate layers were covered by yellow-whitish coloured callus tissues. We observed differences in the number of produced callus in dependency on the accession and PSK- $\alpha$ treatment (Table 3; Fig. 1i, j). The highest number (43 per Petri dish) of callus clumps was scored in alginate layers of breeding line LM153, whereas it was lower (22-27 per Petri dish) in cultivar Kamienna Głowa and breeding line LM. In Oregon 123, we observed on average only nine callus clumps per Petri dish.

Irrespective of genotype, on the PSK-free control medium, we observed an average of seven callus clumps per Petri dish. When PSK- $\alpha$ was added to the medium at a concentration of $0.01 \mu \mathrm{M}$, on average 18 callus clumps per Petri dish were produced. The 10-day treatment of protoplastderived cells with higher concentrations $(0.1$ and $1.0 \mu \mathrm{M})$ of PSK- $\alpha$ significantly increased the average number of callus clumps (33-34) produced per single Petri dish.

Later, the callus colonies were freed from the alginate layers and transferred for regeneration. In the first 2 weeks of culture on a solid medium they turned green, remained whitish or started to brown. Usually, a brown callus did not grow further and was considered dead. Whitish callus clumps slowly increased in size, but no shoot formation was recorded from such structures. Shoot regeneration
Fig. 5 Dynamics of cellulose resynthesis in B. oleracea protoplasts in dependency on culture duration and supplementation of phytosulfokine- $\alpha$ (PSK- $\alpha$ ) into the culture medium. Bars represent means $\pm \mathrm{SE}$

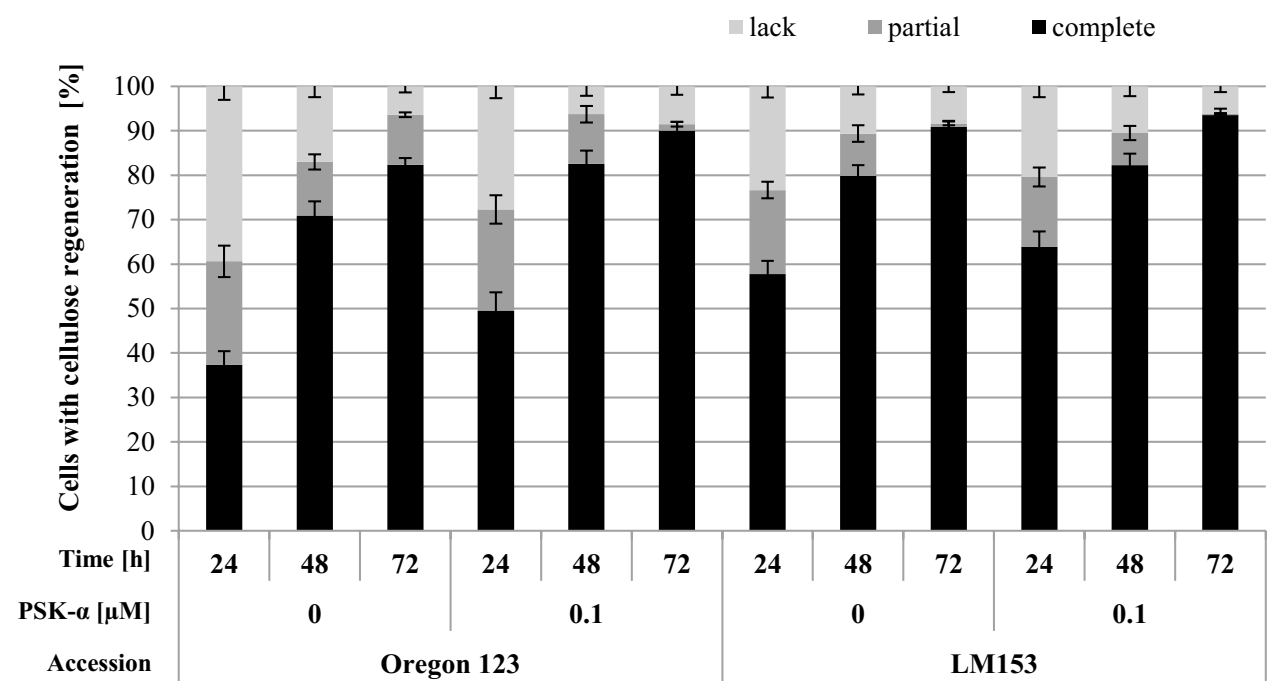


Table 3 Effect of accession and phytosulfokine- $\alpha$ (PSK- $\alpha$ ) treatment on callus production from protoplast-derived $B$. oleracea cells

\begin{tabular}{lcc}
\hline Factor & $\begin{array}{l}\text { Callus clumps/Petri dish } \\
(\text { No. } \pm \text { SE) }\end{array}$ \\
\hline Accession & & \\
Kamienna Głowa & $27.9 \pm 2.1$ & $\mathrm{~b}$ \\
Sława z Gołębiewa & $19.9 \pm 1.4$ & $\mathrm{c}$ \\
Oregon 123 & $9.4 \pm 0.8$ & $\mathrm{~d}$ \\
LM & $22.2 \pm 1.9$ & $\mathrm{bc}$ \\
LM98 & $17.1 \pm 1.8$ & $\mathrm{c}$ \\
LM153 & $42.9 \pm 3.5$ & $\mathrm{a}$ \\
PSK- $\alpha$ concentration $(\mu \mathrm{M})$ in liquid culture media & \\
0 & $7.1 \pm 0.9$ & $\mathrm{c}$ \\
0.01 & $18.3 \pm 1.2$ & $\mathrm{~b}$ \\
0.1 & $33.2 \pm 4.4$ & $\mathrm{a}$ \\
1.0 & $34.1 \pm 4.3$ & $\mathrm{a}$ \\
\hline
\end{tabular}

Means denoted with the same letter are not significantly different $(p \leq 0.05, \mathrm{HSD})$.Values for the factor 'PSK- $\alpha$ concentration $(\mu \mathrm{M})$ in liquid culture media' are means from all tested accessions jointly

Table 4 Shoot regeneration from the protoplast-derived callus colonies of B. oleracea

\begin{tabular}{lll}
\hline Factor & \multicolumn{2}{l}{$\begin{array}{l}\text { Shoot regeneration }(\% \pm \\
\text { SE) }\end{array}$} \\
\hline Accession & & $\mathrm{b}$ \\
Kamienna Głowa & $5.6 \pm 0.9$ & $\mathrm{~b}$ \\
Sława z Gołębiewa & $4.4 \pm 1.0$ & $\mathrm{c}$ \\
Oregon 123 & $0.0 \pm 0.0$ & $\mathrm{a}$ \\
LM & $9.6 \pm 1.5$ & $\mathrm{bc}$ \\
LM98 & $2.5 \pm 0.9$ & $\mathrm{a}$ \\
LM153 & $11.0 \pm 1.2$ & $\mathrm{c}$ \\
Regeneration medium & & $\mathrm{a}$ \\
MS & $2.9 \pm 0.8$ & $\mathrm{c}$ \\
MS $+0.1 \mu$ M PSK- $\alpha$ & $10.2 \pm 1.1$ & $\mathrm{~b}$ \\
B5B & $1.5 \pm 0.4$ & $7.5 \pm 1.2$ \\
B5B $+0.1 \mu$ M PSK- $\alpha$ & & \\
\hline
\end{tabular}

Means denoted with the same letter are not significantly different ( $p \leq 0.05$, HSD). Values for the factor 'Regeneration medium' are means from all tested accessions jointly

was observed from green callus tissues. The first shoots (Fig. 1k) started to appear around 4-6 week after transfer onto solid media. The ability for shoot formation depended on the genotype and the medium (Table 4). After 12 weeks of culture, shoot regeneration varied from 2.5\% (LM98) to $11 \%$ (LM153). No shoots were regenerated form protoplastderived calli of cultivar Oregon 123. We observed a beneficial effect of PSK- $\alpha$ supplemented into solid regeneration medium on shoot development. On the regeneration media without PSK- $\alpha$, the frequency of shoot regeneration ranged from 1.5 (B5B) to $3 \%$ (MS). The addition of $0.1 \mu \mathrm{M}$ PSK- $\alpha$ into the medium increased regeneration frequency almost fourfold compared to the PSK- $\alpha$ free control. The highest (10\%) shoot regeneration was observed on MS medium supplemented with $0.1 \mu \mathrm{M}$ PSK- $\alpha$. Callus tissue cultured on the regeneration media supplemented with PSK- $\alpha$ was often covered by dense white hairy roots (Fig. 11), which was rarely observed in the control.

We observed an interaction between the genotype and media on the regeneration process (Fig. 6). In general, supplementation of both solid regeneration media with $0.1 \mu \mathrm{M}$ PSK- $\alpha$ increased shoot regeneration in all tested accessions, compared to the PSK-free controls. The highest regeneration (17-18\%) was observed in breeding lines LM and LM153 on MS medium with addition of $0.1 \mu \mathrm{M}$ PSK- $\alpha$. This medium was also beneficial for cv. Kamienna Głowa and breeding line LM98, where approximately $9 \%$ of cultured calluses regenerated shoots. In cv. Sława z Gołębiewa, a higher percentage of shoots $(11 \%)$ was observed on medium B5B supplemented with $0.1 \mu \mathrm{M}$ PSK- $\alpha$.

Figure 7 shows the analysis of shoot regeneration capacity dependent on the presence of PSK- $\alpha$ at the early stages of culture (in the liquid medium for culturing the protoplasts, for 10 days), irrespective of its concentration, and in solid media used for regeneration. The highest shoot regeneration (10-14\%) was observed from callus clumps originating from PSK- $\alpha$-treated cultures and later transferred to the regeneration media (MS or B5B) supplemented with $0.1 \mu \mathrm{M}$ of PSK- $\alpha$. Shoot regeneration from calluses originating from control protoplast cultures and later transferred to PSK-free solid regeneration media, was low and did not exceed $1 \%$; however, supplementation of both solid media in $0.1 \mu \mathrm{M}$ of PSK- $\alpha$ increased regeneration to approximately $6 \%$. Shoot regeneration from calluses developed from protoplastderived PSK- $\alpha$-treated cells and later subjected to regeneration on PSK-free B5B and MS solid media was from 2 to $4 \%$, respectively.

\section{Discussion}

Some of the B. oleracea accessions used in this study possess valuable traits (i.e. cytoplasmic male sterility, disease resistance, self-compatibility) that could potentially be introduced into existing cultivars or breeding materials, or combined to produce new genotypes using biotechnological tools, i.e. symmetric/asymmetric protoplast fusion. However, the main obstacle we met during our trials was the low embryogenic potential of such materials, manifested in decreased mitotic activity and/or low or no ability for regeneration. Supplementing the culture medium with PSK (either chemically synthesized or isolated from conditioned medium) promoted proliferation of cells in suspension cultures (Matsubayashi et al. 1996, 1997; Hanai et al. 2000; Grzebelus et al. 2012), 
Fig. 6 Effect of accession and phytosulfokine- $\alpha(0.1 \mu \mathrm{M}$ PSK$\alpha)$-supplemented regeneration media on shoot regeneration from protoplast-derived $B$. oleracea cells. Means denoted with the same letter are not significantly different $(p \leq 0.05$, HSD)

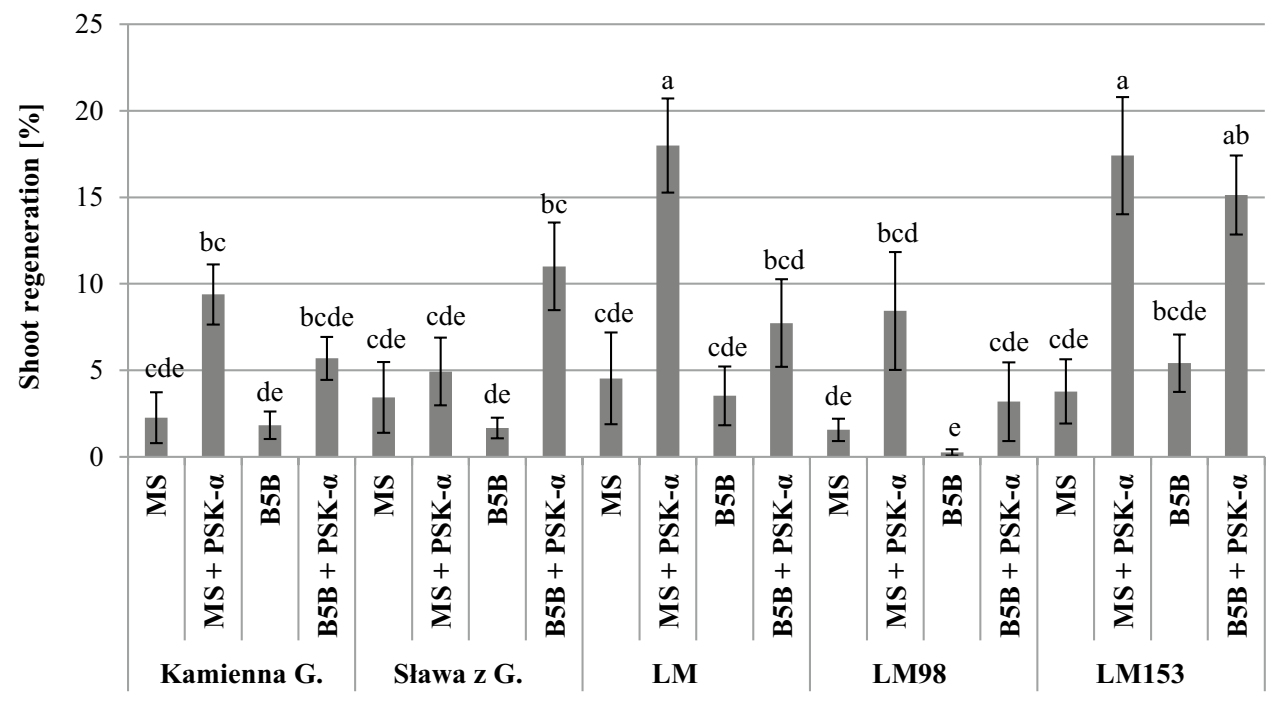

Regeneration media and accession

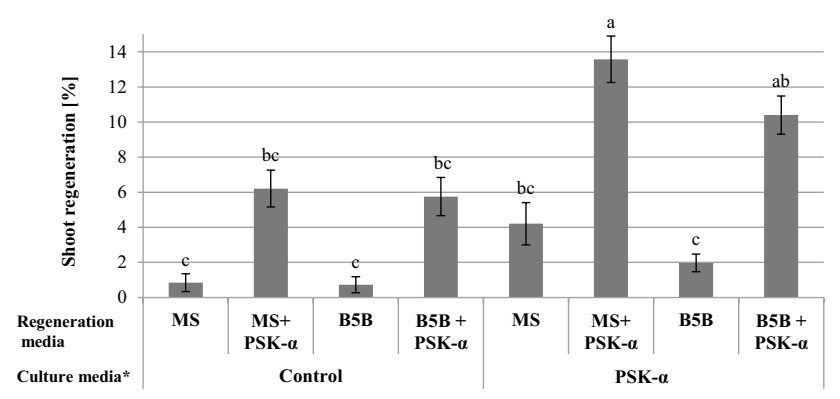

Fig. 7 Effect of phytosulfokine- $\alpha$ (PSK- $\alpha$ ) added at different stages of protoplast culture on shoot regeneration in B. oleracea. * Control-PSK-free liquid medium for protoplast culture; PSK- $\alpha$-liquid medium for protoplast culture supplemented with phytosulfokine- $\alpha$ $(\mathrm{PSK}-\alpha)$ for 10 days, independently from its concentration. Means denoted with the same letter are not significantly different $(p \leq 0.05$, HSD)

and these results were the basis for performing our experiments. A preliminary study on the supplementation of the medium for culturing $B$. oleracea protoplasts with $0.1 \mu \mathrm{M}$ PSK- $\alpha$ showed its beneficial effect on cell division, and the effect of PSK- $\alpha$ was more pronounced in low-responding accessions (Kiełkowska and Adamus 2017). In this study, we wanted to examine (i) whether the effect of PSK- $\alpha$ on cabbage protoplasts is dose-dependent, (ii) whether PSK- $\alpha$ plays a role in cell wall regeneration, which is a prerequisite for cell division, and (iii) whether PSK- $\alpha$ has a direct effect on organogenesis from protoplast-derived callus colonies.

Protoplasts during isolation from the donor tissues undergo various stresses, resulting in physical damage and modification of physiological properties of cells, reflected in decreased viability. It has been shown that a rapid and irreversible increase in the permeability of plasma membranes results in protoplast bursting, electrolyte leakage from the cells, and often cell death (Nolte et al. 1990; Lung et al. 2012). The decrease of protoplast viability might be a result of the damage in plasma membranes during enzyme digestion and purification (Watanabe et al. 2002) but also osmotic stress, or oxidative stress during isolation and culture establishment (Tiburcio et al. 1986). In some cases, protoplasts initially detected as viable lost the ability to regenerate cell walls (incomplete disturbed regeneration) and to divide. The proportion of such cells depends, among others, upon the type of material employed as protoplast source, the procedure of isolation and culture maintenance (Davey et al. 2005; Kiełkowska and Adamus 2012). In such cases, different media supplements are used to promote cell viability and, in that context, viability in the presence of PSK- $\alpha$ was monitored in our study. Our results showed a dose-dependent effect of PSK on cell viability. Cabbage protoplasts cultured in the presence of lower concentrations $(0.01$ and $0.1 \mu \mathrm{M})$ of PSK- $\alpha$ were more viable compared to the PSK-free control. The cells cultured on the media supplemented with the highest concentration $(1.0 \mu \mathrm{M})$ of PSK- $\alpha$ maintained viability on the level observed in the control. The beneficial effect of PSK on cell viability might be associated with its role in osmoregulation involving $\mathrm{K}^{+}$uptake (Stührwohldt et al. 2011).

The process of cell wall reconstruction and the physical and chemical properties of regenerated cell walls affect the mitotic activity of cells (Suzuki et al. 1998). Cellulose ( $\beta$-1,4-glucan) is a major component of plant cell walls, and is synthesized in the plasma membrane and deposited directly into the wall (Doblin et al. 2003). To evaluate the effect of PSK on cell wall development, we tracked the dynamics of cellulose regeneration after staining cells with Calcofluor White. The process of cellulose reconstruction in cabbage protoplasts was non-synchronous, as at the same 
time-point during culture, we observed cells with incomplete reconstruction, including cells with point-aligned cellulose strains, indicating the beginning of the process, as well as cells with completely resynthesized cellulose across the whole cell surface. In the high-responsive accession LM153, the dynamics of cellulose resynthesis was similar in control and in PSK-treated cultures. However, differences were observed for the low-responding Oregon 123. After $24 \mathrm{~h}$ of culture, more cells in which cellulose reconstruction had started, as well as cells with complete cell walls were observed in cultures supplemented in $0.1 \mu \mathrm{M}$ PSK- $\alpha$, compared to PSK-free controls. These results suggest that the stimulation of protoplast-derived cell proliferation by PSK- $\alpha$ might be associated with its effect on the cell wall regeneration process. The link between cell wall development and PSK- $\alpha$ action was previously observed in Arabidopsis. Yu et al. (2016) obtained transgenic plants overproducing functional PSK- $\alpha$, which resulted in male sterility by interfering with fibrous cell wall development in the endothecium.

In our study, the mitotic activity of protoplast-derived cells depended upon the genotype and the presence and concentration of PSK- $\alpha$ in the culture medium. In the bestresponding accession (LM153), the effect of PSK- $\alpha$ was small, as similar frequencies were observed independently of the medium composition, which supports our previous observations (Kiełkowska and Adamus 2017). For the remaining five accessions, PSK- $\alpha$ revealed dose-dependent effects on cell division, and the highest mitotic activity of cultured cells was observed after supplementation of the culture medium with $0.1 \mu \mathrm{M}$ PSK- $\alpha$. These results support earlier findings in other species. Grzebelus et al. (2012) reported the highest plating efficiency $(20 \%)$ from protoplast-derived cells in sugar beet in the presence of $0.1 \mu \mathrm{M}$ PSK- $\alpha$ in the culture medium. This concentration of PSK- $\alpha$ promoted microspore embryogenesis in triticale and wheat (Asif et al. 2014). Similar observations were made in protoplast cultures of different Daucus accessions (Maćkowska et al. 2014), where supplementation of the culture medium with $0.1 \mu \mathrm{M}$ PSK- $\alpha$ led to an increase (55-80\%) in plating efficiency in comparison with the PSK-free control (40-65\%).

In this study, the protoplast-derived cells were cultured in the presence of PSK- $\alpha$ for 10 days, as the media used for replacement was PSK-free. In our previous study, $0.1 \mu \mathrm{M}$ PSK- $\alpha$ was present in the culture medium throughout whole liquid culture phase and was removed before regeneration; the division frequencies for selected accessions were as follows: Sława z Gołębiewa 38\%, Oregon 123 4.5\%, LM 33\%, LM98 47\% (Kiełkowska and Adamus 2017). Comparison of those results with the corresponding results from the present study (0.1 $\mu$ M PSK- $\alpha$ and the same accessions) (Fig. 1) showed that 10-day supplementation of the liquid medium for protoplast culture with this peptide was sufficient to stimulate sustained cell proliferation in all accessions. Interestingly, in low-responding Oregon 123, supplementation of culture medium with $0.1 \mu \mathrm{M}$ PSK- $\alpha$ for 10 days stimulated division in a higher number of cells (14\%, Fig. 1) in comparison with a 4-week culture in the presence of this peptide (4.5\%) (Kiełkowska and Adamus 2017).

Analysis of the developmental stage of cultured cells showed that on the fifth day of culture, the proportion of cells that completed second division but also underwent sustained mitotic divisions (4-8 cell and multi-cell structures) was more frequent in cultures supplemented with PSK- $\alpha$. Later in culture, i.e. after 15 days, multi-celled structures were more numerous in presence of PSK- $\alpha$ than in control cultures. Moreover, at that time, approximately $4 \%$ of cells of the low-responding Oregon 123 cultured in the control medium were identified as 2-cell structures, which suggests that they were arrested at the stage of the second mitotic division. Such structures were not observed in 15-day-old cultures supplemented with PSK- $\alpha$. Matsubayashi et al. (1999a) exposed dispersed asparagus mesophyll cells to $32 \mathrm{nM}$ of PSK- $\alpha$ for various periods $(0-72 \mathrm{~h})$ prior to the first cell division. The ratio of divided cells increased in proportion to the PSK- $\alpha$ exposure periods. Cells exposed to PSK- $\alpha$ for less than $48 \mathrm{~h}$ showed lower mitotic activities $(<50 \%)$ compared to cells subjected to longer exposition $(70-80 \%)$. These results and those obtained in this study, suggest that PSK- $\alpha$ is required before the first cell divisions occur, and might be present in the medium up to the formation of small cell aggregates (20-40 cells); however, its presence is not obligatory later (up to the end of the liquidphase culture).

A beneficial effect of PSK in the stimulation of cell division has been reported for cells cultured in suspension, while in planta, PSK signalling promotes organ growth via enhanced cell size, rather than cell division (Kutschmar et al. 2009; Stührwohldt et al. 2011). Matsubayashi et al. (1999a) studied the kinetics of the production of PSK- $\alpha$ by asparagus mesophyll cells in suspension culture in connection with the effects of auxin and cytokinin on cell divisions. Their results showed that the production of PSK- $\alpha$ began approximately $48 \mathrm{~h}$ before the first cell division, which is generally observed after $96 \mathrm{~h}$ of culture. The production of PSK- $\alpha$ was not observed in the absence of exogenous 1-napthaleneacetic acid (NAA) and/or 6-benzylaminopurine (6-BA) even after $96 \mathrm{~h}$ of culture. Progression in cell cycle and mitosis were observed only when NAA, 6-BA and PSK- $\alpha$ were present in the culture medium, which indicates that the biosynthesis of PSK- $\alpha$ is regulated under a signal transduction pathway activated by auxin and cytokinins. The biosynthesis of phystosulfokines has been reported in cell cultures of Asparagus officinalis, Oryza sativa, Arabisopsis thaliana, Zea mays, Zinnia elegans and Daucus carota (Matsubayashi et al. 1997, 1999b, 2006; Hanai et al. 2000; Yang et al. 2001; 
Stührwohldt et al. 2011). Here, the basal medium for culturing protoplasts contained $0.1 \mathrm{mg} \mathrm{l}^{-1} 2,4-\mathrm{D}$ and $0.2 \mathrm{mg} \mathrm{l}^{-1}$ zeatin, and PSK- $\alpha$ was exogenously incorporated into the culture medium. The protoplast-derived cells of most of the tested accessions divided more frequently in the presence of 2,4-D and zeatin coupled with PSK- $\alpha$ compared to control medium containing both growth hormones but PSK-free. Such results suggest that 2,4-D and zeatin being present in the control medium were less effective in the stimulation of cell divisions in cabbage compared to the combination of both hormones and PSK- $\alpha$. PSK biosynthesis was not monitored in our study and, to the best of our knowledge, there are no reports on biosynthesis of phytosulfokines in cabbage; however, this cannot be excluded, as a PSK homologue gene has been identified in other Brassica, namely, $B$. napus (Lorbiecke and Sauter 2002). We speculate that, even if the PSK biosynthesis took place in the presence of applied auxin and cytokinin, the amount of PSK produced was not as sufficient for the induction of cell divisions as its exogenous supplementation in cabbage protoplast cultures.

Protoplast culture in $B$. oleracea remains limited by genotypic differences in the ability to regenerate (Jourdan et al. 1990; Walters and Earle 1990; Kiełkowska and Adamus 2012, 2014). In this study, successful regeneration was obtained in five out of six tested accessions. Protoplastderived cells of Oregon 123 divided the least frequently, and the number of callus clumps obtained per single layer was also the lowest. The callus clumps, despite culturing on the solid medium with PSK- $\alpha$, failed to regenerate. Studies on the effect of PSK- $\alpha$ on somatic embryogenesis showed that its exogenous application to fresh embryogenic cell cultures in presence of 2,4-D stimulated cell proliferation but did not stimulate further differentiation into somatic embryos (Kobayashi et al. 1999). Protoplast-derived cells of six different sugar beet accessions (Grzebelus et al. 2012) and two out of seven wild Daucus accessions (Maćkowska et al. 2014) were effectively stimulated to divide by PSK- $\alpha$ present in the medium; however, regeneration from such cultures was not observed. The cited results and those obtained in our study showed that PSK- $\alpha$ is beneficial for launching proliferation of cells cultured in suspension, however, not always sufficient for its maintenance. Hanai et al. (2000) showed that PSK was not capable of inducing embryogenic competence in non-embryogenic cells of carrot. The main reason for the failure of cell development in suspension cultures is associated with cell density; however, in the cited studies and in ours, the density for cell culturing was optimal. Another explanation might be secretion of the inhibitors into the culture media. Higashi et al. (1998) showed that the inhibition of carrot somatic embryo formation was due to endogenous factors (molecular weights $<3500$ ) released into the conditioned medium. Similar observations were reported in suspension cultures of Japanese larch, where an inhibitory factor was identified as vanillyl benzyl ether (Umehara et al. 2005b). Thus, the lack of further cell development in the presence of PSK might be due to possible competition of this peptide with the inhibitory factor(s).

To study the effect of PSK- $\alpha$ on microcalli production, we used an equal volume $(400 \mu \mathrm{l})$ of alginate-protoplast mixture to produce alginate layers. The density of cells in each layer and the volume of culture medium in which the layers were submerged were the same. Supplementation of the liquid culture medium with PSK- $\alpha$ caused an increase in the number of callus clumps produced per single layer compared to the PSK-free control. Additionally, the average number of protoplast-derived calli produced per single layer cultured in the media supplemented with $0.1 \mu \mathrm{M}$ PSK- $\alpha$ was similar to that, observed on the medium supplemented with $1.0 \mu \mathrm{M}$ PSK- $\alpha$. Such results show that this high concentration of PSK- $\alpha$ in the culture media did not increase callus production, in agreement with previous observations that PSK is most active at very low (nanomolar) concentrations (Matsubayashi et al. 1999a, b; Yang et al. 1999b, 2001).

The obtained callus colonies were subjected to regeneration on solid media. To test the direct effect of PSK- $\alpha$ on the process, both regeneration media were supplemented with $0.1 \mu \mathrm{M}$ PSK- $\alpha$, and PSK-free media were used as controls. The results showed an approximate 3-5-fold increase in the frequency of regeneration from protoplastderived calluses cultured on the regeneration media containing PSK- $\alpha$ in comparison to PSK-free controls. In our previous study, we observed an indirect effect of PSK- $\alpha$ on regeneration, reflected in the higher number of shoots produced form cultures supplemented with PSK- $\alpha$ at the liquid culture stage and transferred for regeneration onto PSK- $\alpha$ free media (Kiełkowska and Adamus 2017). The results obtained in this study also support these observations, as the increase in regeneration from calluses developed from protoplast-derived cells cultured in the presence of PSK- $\alpha$ (2-4\%) was also detectable in comparison to the PSK-free controls $(0.7-0.8 \%)$. However, our results showed that the best response was observed when protoplast-derived cells were cultured in the presence of PSK- $\alpha$ for 10 days and then transferred for regeneration on the media supplemented also with this peptide (Fig. 7).

Enhancement of the regeneration competence by supplementation of the regeneration media with PSK was very recently reported for two grain legumes species (Ochatt et al. 2018). In pea, PSK- $\alpha$ enhanced regeneration by promoting of somatic embryos development and organogenesis, what resulted in plant formation. In faba bean, PSK- $\alpha$ induced somatic embryogenesis, however, somatic embryos failed to convert into plants. Our study also supports these findings, as supplementation of the regeneration media in PSK- $\alpha$ significantly increased organogenesis compared to control cultures. The differences in shoot regeneration between 
tested cabbage accessions cultured on the solid media supplemented with PSK were observed. Moreover, for some accessions, i.e. LM, LM153, the highest number of shoots was observed on hormone-free MS medium supplemented with $0.1 \mu \mathrm{M}$ of PSK- $\alpha$. Both these accessions shown to be relatively high-responsive to protoplast cultures. Such results suggest that for high responsive cabbage genotypes, for the induction of organogenesis from a protoplast-derived callus in the presence of PSK- $\alpha$, other growth regulators might not be obligatory.

Callus tissue obtained from protoplast-derived cells cultured on the regeneration medium with PSK- $\alpha$ often developed hairy roots, which was rare among the callus tissues cultured on the PSK-free controls. It has been shown that PSK signalling regulates root and hypocotyl elongation of Arabidopsis seedlings (Kutschmar et al. 2009; Stührwohldt et al. 2011). Thus, we presumed that the enhanced growth of $B$. oleracea hairy roots observed in our study could be stimulated by PSK- $\alpha$.

\section{Conclusions}

Our study showed that the effect of exogenous PSK- $\alpha$ on protoplast cultures is genotype- and dose- dependent. Protoplast-derived cells of cabbage do not require constant presence of PSK- $\alpha$ in the liquid culture medium for maintaining cell divisions. PSK- $\alpha$ is not capable of inducing embryogenic competence in non-embryogenic cells, but it seems to reactivate or maintain the cellular potential to proliferate in response to endogenous or external stimuli, i.e. other growth regulators. PSK- $\alpha$ has an effect on the dynamics of resynthesis of cellulose in cabbage protoplasts, which is a prerequisite to undergo cell divisions. This effect was especially pronounced in low-responding accessions. PSK- $\alpha$ promotes not only cell proliferation, but also differentiation and organogenesis in cabbage. Obtained results suggest a genotype-dependent effect of PSK on the regeneration process.

Acknowledgements This research was supported by the Polish Ministry of Agriculture and Rural Development (No. HORhn4040 dec-1/08, 2008-2013) and by the Ministry of Science and Higher Education of Poland (DS3500). The authors would like to thank Lucyna Samek, Marta Solarz and Adriana Koterwas for excellent work with protoplast cultures.

Author Contributions KA concept, design of the experiment, statistical analysis, writing and preparing the manuscript; AA had a role in the concept and critically revised the manuscript.

\section{Compliance with Ethical Standards}

Conflict of interest The authors declare that they have no conflict of interest.
Open Access This article is distributed under the terms of the Creative Commons Attribution 4.0 International License (http://creativeco mmons.org/licenses/by/4.0/), which permits unrestricted use, distribution, and reproduction in any medium, provided you give appropriate credit to the original author(s) and the source, provide a link to the Creative Commons license, and indicate if changes were made.

\section{References}

Arasimowicz M, Floryszak-Wieczorek J (2007) Nitric oxide as a bioactive signalling molecule in plant stress responses. Plant Sci 172:876-887

Asif M, Eudes F, Randhawa H, Amundsen E, Spaner D (2014) Phytosulfokine alpha enhances microspore embryogenesis in both triticale and wheat. Plant Cell Tiss Organ Cult 116:125-130

Bishop GJ, Yokota T (2001) Plant steroid hormones, brassinosteroids: current highlights of molecular aspects on their synthesis/metabolism, transport, perception and response. Plant Cell Physiol 42:114-120

Constabel CP, Yip L, Ryan CA (1998) Prosystemin from potato, black nightshade, and bell pepper: primary structure and biological activity of predicted systemin polypeptides. Plant Mol Biol 36:55-62

Davey MR, Anthony P, Power JB, Lowe KC (2005) Plant protoplasts: status and biotechnological perspectives. Biotechnol Adv 23:131-171

Dirks R, Sidorov V, Tulmans C (1996) A new protoplast culture in Daucus carota L. and its applications for mutant selection and transformation. Theor Appl Genet 93:809-815

Doblin MS, Vergara CE, Read SM, Newbigin E, Bacic A (2003) Plant cell wall biosynthesis: making the bricks. In: Rose JKC (ed) The plant cell wall. Blackwell, Hoboken, pp 183-222

Fletcher JC, Brand U, Running MP, Simon R, Meyerowitz EM (1999) Signaling of cell fate decisions by CLAVATA3 in Arabidopsis shoot meristems. Science 283:1911-1914

Gamborg OL, Miller RA, Ojima K (1968) Nutrient requirements of suspension cultures of soybean root cells. Exp Cell Res $50: 151-158$

Grosser JW, Gmitter FG Jr (2005) Thinking outside the cell - applications of somatic hybridization and cybridization in crop improvement, with citrus as a model. In Vitro Cell Dev Plant 41:220-225

Grzebelus E, Szklarczyk M, Greń J, Śniegowska K, Jopek M, Kacińska I, Mrożek K (2012) Phytosulfokine stimulates cell divisions in sugar beet (Beta vulgaris L.) mesophyll protoplast cultures. Plant Growth Regul 67:93-100

Hanai H, Matsuno T, Yamamoto M, Matsubayashi Y, Kobayashi T, Kamada H, Sakagami Y (2000) A secreted peptide growth factor, phytosulfokine, acting as a stimulatory factor of carrot somatic embryo formation. Plant Cell Physiol 41:27-32

Higashi K, Daita M, Kobayashi T, Sasaki K, Harada H, Kamada H (1998) Inhibitory conditioning for carrot somatic embryogenesis in high-cell-density cultures. Plant Cell Rep 18:2-6

Igasaki T, Akashi N, Ujino-Ihara T, Matsubayashi Y, Sakagami Y, Shinohara K (2003) Phytosulfokine stimulates somatic embryogenesis in Cryptomeria japonica. Plant Cell Physiol 44:1412-1416

Jang JC, Fujioka S, Tasaka M, Seto H, Takatsuto S, Ishii A, Aida M, Yoshida S, Sheen J (2000) A critical role of sterols in embryonic patterning and meristem programming revealed by the fackel mutants of Arabidopsis thaliana. Genes Dev 14:1485-1497

Jourdan PS, Earle ED, Mutschler MA (1990) Improved protoplast culture and stability of cytoplasmic traits in plants regenerated from leaf protoplasts of cauliflower (Brassica oleracea ssp. botrytis). Plant Cell Tissues Organ Culture 21:227-236 
Kao KN, Michayluk MR (1975) Nutritional requirements for growth of Vicia hajastana cells and protoplasts at a very low population density in liquid media. Planta 126:105-110

Kiełkowska A, Adamus A (2012) An alginate-layer technique for culture of Brassica oleracea L. protoplasts. In Vitro Cell Dev Biol 48:265-273

Kiełkowska A, Adamus A (2014) Embedding in filter sterilized alginate enhances Brassica oleracea L. protoplast culture. Acta Biol Crac Ser Bot 56/2:20-26

Kiełkowska A, Adamus A (2017) Early studies on the effect of peptide growth factor phytosulfokine- $\alpha$ on Brassica oleracea var. capitata L. protoplasts. Acta Soc Bot Pol 86(3):3558

Kik C, Zaal MACM (1993) Protoplast culture and regeneration from Brassica oleracea 'rapid cycling' and other varieties. Plant Cell Tissues Organ Culture 35:107-114

Kobayashi T, Eun CH, Hanai H, Matsubayashi Y, Sakagami Y, Kamada H (1999) Phytosulphokine-a, a peptidyl plant growth factor, stimulates somatic embryogenesis in carrot. J Exp Bot 50:1123-1128

Kutschmar A, Rzewuski G, Stührwohldt N, Beemster GTS, Inzé D, Sauter M (2009) PSK- $\alpha$ promotes root growth in Arabidopsis. New Phytol 181:820-831

Lakshmanan PS, Eeckhaut T, Deryckere D, Van Bockstaele E, Van Huylenbroeck J (2013) Asymmetric somatic plant hybridization: status and applications. Am J Plant Sci 4:1-10

Lindsey K, Casson S, Chilley P (2002) Peptides: new signalling molecules in plants. Trends Plant Sci 7:78-83

Lorbiecke R, Sauter M (2002) Comparative analysis of PSK peptide growth factor precursor homologs. Plant Sci 163:321-332

Lung S-C, Yanagisawa M, Chuong SDX (2012) Isolation of dimorphic chloroplasts from the single-cell $\mathrm{C}_{4}$ species Bienertia sinuspersici. Plant Methods 8(1):8

Maćkowska K, Jarosz A, Grzebelus E (2014) Plant regeneration from leaf-derived protoplasts within the Daucus genus: effect of different conditions in alginate embedding and phytosulfokine application. Plant Cell Tissue Organ Culture 117:241-252

Matsubayashi Y, Sakagami Y (1996) Phytosulfokine, sulfated peptides that induce the proliferation of single mesophyll cells of Asparagus officinalis L. Proc Natl Acad Sci 93:7623-7627

Matsubayashi Y, Hanai H, Hara O, Sakagami Y (1996) Active fragments and analogs of the plant growth factor, phytosulfokine: structure-activity relationship. Biochem Biophys Res Commun 225:209-214

Matsubayashi Y, Takagi L, Sakagami Y (1997) Phytosulfokinealpha, a sulfated pentapeptide, stimulates the proliferation of rice cells by means of specific high-and low-affinity binding sites. Proc Natl Acad Sci 94:13357-13362

Matsubayashi Y, Morita A, Matsunaga E, Furuya A, Hanai N, Sakagami Y (1999a) Physiological relationships between auxin, cytokinin, and a peptide growth factor, phytosulfokine-alpha, in stimulation of asparagus cell proliferation. Planta 207:559-565

Matsubayashi Y, Takagi L, Omura N, Morita A, Sagakami Y (1999b) The endogenous sulfated pentapeptide phytosulfokine-alpha stimulates tracheary element differentiation of isolated mesophyll cells of zinnia. Plant Physiol 120:1043-1048

Matsubayashi Y, Ogawa M, Kihara H, Niwa M, Sakagami Y (2006) Disruption and overexpression of Arabidopsis phytosulfokine receptor gene affects cellular longevity and potential for growth. Plant Physiol 142:45-53

Matsuzaki Y, Ogawa-Ohnishi M, Mori A, Matsubayashi Y (2010) Secreted peptide signals required for maintenance of root stem cell niche in Arabidopsis. Science 329:1065-1067

Menczel L, Nagy F, Kiss Z, Maliga P (1981) Streptomycin resistant and sensitive somatic hybrids of Nicotiana tabacum + Nicotiana knightiana: correlation of resistance to $N$. tabacum plastids. Theor Appl Genet 70:590-594
Mosher S, Seybold H, Rodriguez P, Stahl M, Davies KA, Dayaratne S, Morillo SA, Wierzba M, Favery B, Keller H, Tax FE, Kemmerling B (2013) The tyrosine-sulfated peptide receptors PSKR1 and PSY1R modify the immunity of Arabidopsis to biotrophic and necrotrophic pathogens in an antagonistic manner. Plant J 73:469-482

Murashige T, Skoog F (1962) A revised medium for rapid growth and bioassays with tobacco tissue cultures. Physiol Plant $15: 473-497$

Nolte KD, Nothnagel EA, Coggins CW Jr (1990) Electrolyte leakage and protoplasm viability of Pummelo mesocarp tissue as influenced by exogenous $\mathrm{GA}_{3}$. J Am Soc Hortic Sci 115:592-597

Ochatt S, Conreux C, Moussa Mcolo R, Despierre G, Magnin-Robert J-B, Raffiot B (2018) Phytosulfokine-alpha, an enhancer of in vitro regeneration competence in recalcitrant legumes. Cell Tissue Organ Culture. https://doi.org/10.1007/s11240-018-1455-0

Pearce G, Strydom D, Johnson S, Ryan C (1991) A polypeptide from tomato leaves induces wound-inducible proteinase inhibitor proteins. Science 253:895-898

Reymond P, Farmer EE (1998) Jasmonate and salicylate as global signals for defense gene expression. Curr Opin Plant Biol 1:404-411

Rotwein P (1997) Peptide growth factors. In: Conn MP, Melmed S (eds) Endocrinology - basic and clinical principles. Springer, New York, pp 79-100

Sporn MB, Roberts AB (1991) The multifunctional nature of peptide growth factors. In: Sporn MB, Roberts AB (eds) Peptide growth factors and their receptors I. Springer, New York, pp 3-15

Stührwohldt N, Dahlke RI, Steffens B, Johnson A, Sauter M (2011) Phytosulfokine-a controls hypocotyl length and cell expansion in Arabidopsis thaliana through phytosulfokine receptor. PLoS ONE 6(6): 21054

Stührwohldt N, Dahlke RI, Kutschmar A, Peng X, Sun MX, Sauter M (2015) Phytosulfokine peptide signaling controls pollen tube growth and funicular pollen tube guidance in Arabidopsis thaliana. Physiol Plant 153(4):643-653

Suzuki K, Itoh T, Sasamoto H (1998) Cell wall architecture prerequisite for the cell division in the protoplasts of white poplar, Populus alba L. Plant Cell Physiol 36:632-638

Tiburcio AF, Kaur-Sawhney R, Galston AW (1986) Polyamine Metabolism and osmotic stress - relation to protoplast viability. Plant Physiol 82:369-374

Umehara M, Ogita S, Sasamoto H, Eun C-H, Matsubayashi Y, Sakagami Y, Kamada H (2005a) Two stimulatory effects of the peptidyl growth factor phytosulfokine during somatic embryogenesis in Japanese larch (Larix leptolepis Gordon). Plant Sci 169:901-907

Umehara M, Ogita S, Sasamoto H, Koshino H, Asami T, Fujioka S, Yoshida S, Kamada H (2005b) Identification of a novel factor, vanillyl benzyl ether, which inhibits somatic embryogenesis of Japanese larch (Larix leptolepis Gordon). Plant Cell Physiol 46:445-453

van de Sande K, Pawlowski K, Czaja I, Wienek U, Schell J, Schmidt J, Walden R, Matvienko M, Wellink J, van Kammen A, Franssen $\mathrm{H}$, Bisseling $\mathrm{T}$ (1996) Modification of phytohormone response by a peptide encoded by ENOD40 of legumes and a nonlegume. Science 273:370-373

Vanoosthuyse V, Miege C, Dumas C, Cock JM (2001) Two large Arabidopsis thaliana gene families are homologous to the Brassica gene superfamily that encodes pollen coat proteins and the male component of the self-incompatibility response. Plant Mol Biol 46:17-34

Waara S, Glimelius K (1995) The potential of somatic hybridization in crop breeding. Euphytica 85:217-233

Walters TW, Earle ED (1990) A simple, versatile feeder layer system for Brassica oleracea protoplast culture. Plant Cell Rep 9:316-319 
Watanabe M, Setoguchi D, Uehara K, Ohtsuka W, Watanabe Y (2002) Apoptosis-like cell death of Brassica napus leaf protoplasts. New Phytol 156:417-426

Yamakawa S, Sakuta C, Matsubayashi Y, Sakagami Y, Kamada H, Satoh S (1998) The promotive effects of a peptidyl plant growth factor, phytosulfokine- $\alpha$, on the formation of adventitious roots and expression of a gene for a root-specific cystatin in cucumber hypocotyls. J Plant Res 111:453-458

Yamakawa S, Matsubayashi Y, Sakagami Y, Kamada H, Satoh S (1999) Promotive effects of the peptidyl plant growth factor, phytosulfokine-alpha, on the growth and chlorophyll content of Arabidopsis seedlings under high night-time temperature conditions. Biosci Biotechnol Biochem 63:2240-2243

Yang G, Shen S, Kobayashi T, Matsubayashi Y, Sakagami Y, Kamada H (1999a) Stimulatory effects of a novel peptidyl plant growth factor, phytosulfokine- $\alpha$, on adventitious bud formation in Antirrhinum majus. Plant Biotechnol 16:231-234
Yang H, Matsubayashi Y, Nakamura K, Sakagami Y (1999b) Oryza sativa PSK gene encodes a precursor of phytosulfokine-alpha, a sulfated peptide growth factor found in plants. Proc Natl Acad Sci 96:13560-13565

Yang HP, Matsubayashi Y, Nakamura K, Sakagami Y (2001) Diversity of Arabidopsis genes encoding precursors for phytosulfokine, a peptide growth factor. Plant Physiol 127:842-851

Yu L, Liu Y, Li Q, Tang G (2016) Overexpression of phytosulfokinea induces male sterility and cell growth by regulating cell wall development in Arabidopsis. Plant Cell Rep 35:2503-2512

Zhao K-N, Bittisnich DJ, Halloran GM, Whitecross MI (1995) Studies of cotyledon protoplast cultures from B. napus. B. campestris and B. oleracea. II: Callus formation and plant regeneration. Plant Cell Tissue Organ Culture 40:73-84 